\title{
WELCOME TO THE RARE EARTH FRONTIER
}

\begin{abstract}
Non-availability means that resource conflict is an immediate threat with negative short- and long-term geostrategic consequences.
\end{abstract}

—Rare Earth Elements World Report (June 21, 2012)

The problem we face on earth is that beyond their scarcity, these elements are not evenly distributed throughout the world. We need to disrupt this market. By finally being able to reach the Moon and harvest the resources that are there, we can overcome the scarcity of rare earth elements and create the infrastructure necessary for innovation to continue.

—Naveen Jain, Founder of Moon Express (May 24, 2012)

\author{
Unfortunately, "strategic metals" are among those perennially \\ misunderstood policy issues with strange lives of their own. The myth \\ of shortage simply refuses to die. \\ —Russell Seitz and Jerry Taylor (July 28, 2005)
}

Rare earths are not rare. Because they were unknown at the time of their discoveryas most things are-they were presumed to be rare. Such faulty thinking would shape the political life of these elements from the moment they were first identified in 1794 until the present.

It is true that rare earths are so thoroughly integrated into our everyday lives that just about everything would grind to a halt without them. They enable both the hardware and the software of contemporary life to be lighter, faster, stronger, and longer ranging. The incredible array of essential applications will be discussed later, but the good news is that rare earth elements are not at all rare on earth. These seventeen chemically similar elements, distinguished by their exceptional magnetic and conductive properties, abound in Earth's crust. The bad news is that minable rare earth deposits coincide with all sorts of other hazardous elements: uranium, thorium, arsenic, fluoride, and other heavy metals.

Yet even this is insufficient to explain our contemporary circumstances, wherein 97 percent of global production concentrated in China in 2010 (see figure 1). 


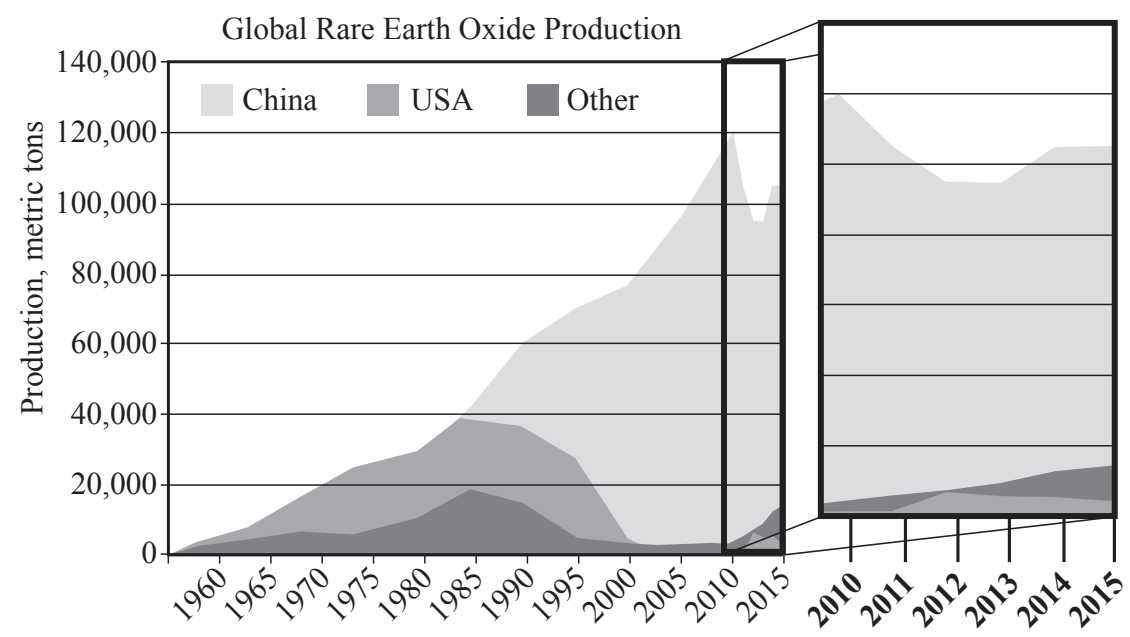

FIGURE 1. Global rare earth oxide production.

Sources: Data compiled from Information Office of the State Council (2010); Orris and Grauch (2013); and United States Geological Survey (2016). Image by Molly Roy.

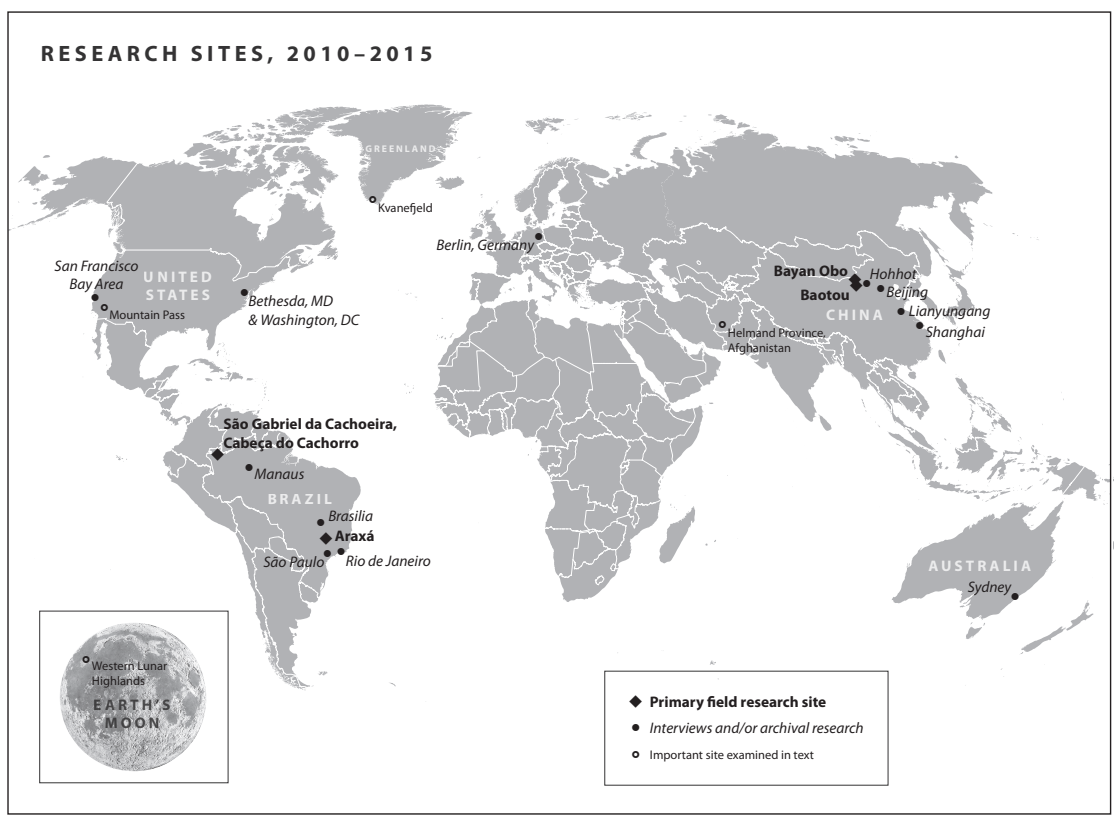

FIGURE 2. This map indicates research sites visited in 2010-2015, with the exception of the Moon.

Source: Image by Molly Roy. 


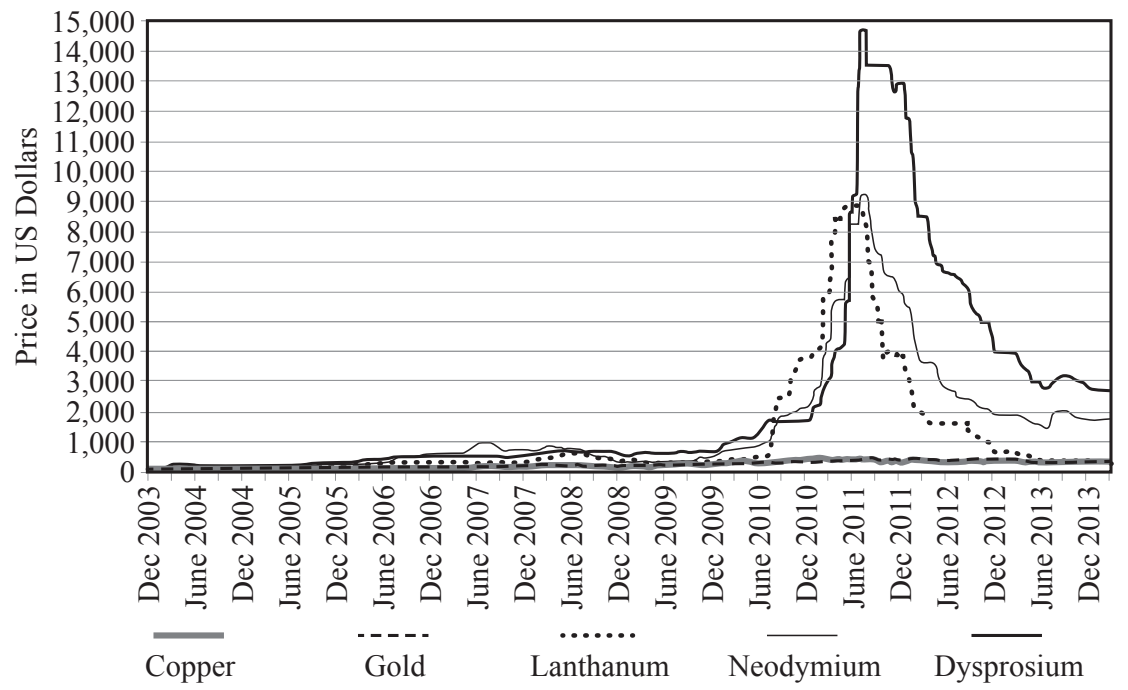

FIGURE 3. Price index USD/kg for selected rare earth oxides, 2003-2013, compared to copper and gold. Prices rebased to 100 for fourth quarter of 2003.

Source: Bartekova (2014). Image by Molly Roy.

Against this situation, unexpected alliances have emerged to attempt mining rare earths in impossible places. The second decade of the twenty-first century saw campaigns to mine rare earths in the most forbidding of frontiers: in ecologically sensitive indigenous lands in the Amazon, in war-torn Afghanistan, in protected areas of Greenland, in the depths of the world's oceans, and even on the Moon.

Currently, rare earths elements are mined and processed in ways that generate tremendous harm to surrounding environs and their inhabitants. In my primary research sites, the abandoned homes and noxious waterways provided visible evidence of the costs of mining for global consumption without regard for local landscapes and lives. Less visible but more profound were the devastating effects on the bodies of people living nearby and downstream of these operations. Cancers, birth defects, and the decomposition of living people's musculoskeletal systems: these constitute an epidemiological crisis affecting some two million people in northern China and many others living former rare earth production sites in Southern California, Malaysia, and Central Asia.

There are readily available alternatives to this devastating state of affairs. Since 2010, some firms have invested in building the industrial capacity to expand more sustainable production practices. Researchers on three continents have launched initiatives to improve recycling techniques. All of this is supported by growing 
movements of people committed to cleaning up the lifecycles of our everyday technologies. With unprecedented public awareness of these elements and their importance, the time would seem ripe to make our systems of rare earth production and consumption greener, safer, and more reliable.

But we have not yet risen to the occasion. In fact, until relatively recently, few knew what rare earths were or why they mattered. Even fewer demonstrated concern over the tremendous harms generated by contemporary rare earth production practices. Fewer still were those contemplating how we are all implicated and endangered not only by the devastation wrought by their production but also by alarmist reactions to our contemporary situation. In 2010, this began to change.

What happened?

\section{The Situation and the Questions}

In late September 2010, China's military blocked a routine shipment of rare earth elements to Japan. What was initially an independent maneuver at a single port facility by the People's Liberation Army in the ongoing tensions between the two countries came to be interpreted by the international community as China flexing its geoeconomic muscle. China's foreign ministry intervened to resume shipments in November 2010 and later denied that such a disruption had taken place. But the rude awakening had already happened (Areddy, Fickling, and Shirouzu 2010; Bradsher 2010; Hur 2010). China then provided over 97 percent of the global supply of rare earth elements on which nearly every industrial country depends, and for which there were no synthetic alternatives.

Although annual global consumption remains at a relatively modest 120,000 tonnes (Castilloux 2014), ${ }^{1}$ rare earth elements define modern life. Without them, the technologies on which we rely for global communication, transportation, medicine, and militarism, as well as nuclear, petroleum-based, and renewable energy production would not exist. Sudden supply disruptions had never occurred since the elements had become so thoroughly embedded in contemporary life.

Over a decade prior to the 2010 incident, China's central government began implementing policies to curb rare earth production in response to alarming environmental crises in mining regions, and to enforce export quotas to mitigate against the perceived threat of resource exhaustion (Chen 2010). The first discernible effect of these policies occurred in 2008, marking the first year in which exports decreased relative to the previous year (Zepf 2013). Then between 2008 and 2011, prices increased as much as 2,000 percent for some elements. For example, dysprosium, an element used in commercial lighting, lasers, and hard drives, rose from US $\$ 110 / \mathrm{kg}$ in 2008 to US $\$ 2,031 / \mathrm{kg}$ in 2011 (see figure 3). As an 
indicator of how this affected downstream industry, one study found that the price increases between July and September 2011 reduced the net income of a major hard drive producer in the United States by 37 percent (Monahan 2012). Others reported "a chilling effect" on renewable energy start-ups in the Euro-American world (Bradsher 2011a), while still others claimed that dependence on China for materials used in critical defense applications posed a "national security threat" to the United States and allied countries (Coppel 2011).

Prices began rising in 2008, but not until late 2010 did China's monopoly come to be seen as a global threat, prompting market panic and unleashing waves of speculation, prospecting, and bellicose political discourse across the world (Caramenico 2012; Z. Chen 2011; Fulp 2011). It was no longer invisible within the global economic status quo prevailing since the 1980s. Rare earth mining and processing, and increasingly, the production of critical technological components, followed the trajectory of many global industries as they concentrated in China in search of cheaper labor and fewer environmental regulations. During the latter decades of the twentieth century, the deindustrialization of much of the West intersected with its mirror opposite in China: massive state-directed initiatives of integrated scientific and industrial development in certain strategic sectors. The result of these intersecting processes is the contemporary East Asian dominance in heavy industry and manufacturing that defines the present. But rather than address the issue in a substantive or historically informed manner, Anglophone commentators unleashed a sensationalist maelstrom describing the concentration of rare earth production in China as a "stranglehold" (Evans-Pritchard 2013) that threw the world into "crisis" (Bourzac 2011) and constituted a "threat" (Hannis 2012) to the national security and economic stability of downstream countries (Portales 2011). In such a framing, the actual origins of China's rare earth monopoly were obscured by accusations of conspiracy and geopolitical posturing.

The situation prompted a flurry of dramatic responses and counterstrategies across the globe. ${ }^{2}$ For example, since the crisis of 2010, economic officials within the United States, European Union (EU), and Japan acknowledged that their dependence on China's rare earths arose from longer-term shifts in the global division of labor, whereby dirty industry relocated to China and then undersold Western firms to the point of their bankruptcy. Several elected officials publicly advocated for national plans to revive domestic industries in the Americas (Bennett 2010; Clancy and Banner 2012). Although such initiatives would have required significant political and technological capital, the urgency of the period between 2010 and 2013 inspired efforts to restore domestic capacity through rather creative means, as illustrated by the Brazil and US cases examined in chapter 4. But at the same time, the United States, EU, and Japan filed a WTO suit against China's production and export quotas in order to preserve the very global 
division of labor that had brought about the demise of rare earth mining and processing industries in the West.

The extent of the actual shortage of rare earth oxides in 2010 is debatable. But the very possibility drew together diverse currents circulating in different parts of the world. Growing international anxieties with respect to China's rise, creeping resource nationalism, and frustrated bids for geopolitical power: these collided with the shock of sudden awareness of dependence on China into a perfect storm that drove mining interests into previously protected places across the globe and even beyond. China's contemporary rare earth production dominance-or more precisely, the delayed international response to the central government's decade-old decisions to curb output_-impelled the opening of vast new horizons on the global rare earth frontier: stimulating new investments in prospecting and mining activities while renewing struggles over who bears the staggering environmental costs of production. Each of these developments are driven by the strategic value with which these elements are imbued, underscored by the specter of price volatility, perceived global supply shortages, and the stubborn fiction that rare earths are, in fact, rare (Brown 2013; Lima 2012; Ting and Seaman 2013; Wang 2010).

The importance and relative ubiquity of rare earth elements would seem more likely to drive exploitation "closer to home," so to speak, in well-connected regions within major consuming economies. However, this is not the case. Instead, in the race to open up rich new extraction points, less remote, apparently easier to access deposits have been overlooked in favor of the far northwestern Amazon and the Moon.

In 2011, Brazil's Rousseff administration issued a public call to mining firms to evaluate the feasibility of exploiting rare earth deposits on indigenous territory in a sensitive border region of the far northern Amazon, while the National Aeronautics and Space Administration (NASA) and the US Department of Defense partnered with Silicon Valley firms to develop the required technological and legal infrastructure to extract these elements from the Moon. US entities have not been the only ones seeking these elements beyond Earth: China successfully landed the Jade Rabbit lunar rover on the Moon on December 14, 2013, with the purpose of gathering scientific data and exploring for minable minerals, including rare earths (Radio 2013; Shefa 2014; Wang 2013).

Perhaps such agitation would make sense if rare earth elements were, in fact, rare. But many are more abundant than copper, as common as lead, and as of late 2015 there were more than 800 known minable land-based deposits ${ }^{3}$ on Earth. In the years since the crisis, herculean efforts to open up new production sites have modestly reduced China's share of global production. In 2015, China produced 85 percent of all rare earth elements consumed worldwide. Mean- 
while, hundreds of new mining initiatives have failed. But some-such as the far-flung campaigns examined herein-persist in defiance of familiar market logics.

Unfortunately, this hyperbolic behavior has been supported by hyperbolic commentary. A few popular nonfiction books on rare earths emerged in the aftermath of 2010 (Veronese 2015; Wang 2010), and tellingly, even more works of fiction on the same theme have been published (Asher 2015; Besson and Weiner 2016; Bunn 2012; Mason 2012; Sellers 2016). If books-both fiction and nonfiction-on the topic of resource scarcity that make only brief mention of rare earths are included, the list grows prodigiously. Without exception, all emphasize the threat posed by global dependence on China and paint apocalyptic pictures of urgently intensifying geopolitical contest in a fictitious context of disappearing global resources. In describing the putative "race for what's left" (Klare 2013), their objectives are to illustrate rather than deconstruct the status quo as perceived from the more paranoid segments of the English, French, or Chinese speaking world. This has had the result of amplifying bellicose discourses at the expense of opening new lines of inquiry toward more collaborative solutions. By reciting powerful tropes that have emerged in the confusion surrounding rare earths, these works obscure far more than they clarify. None of these works are supported by in-depth site-specific research, much less engage the multiple stakeholders or volumes of primary source materials in languages local to the mining sites. The sole exception is the 2015 The Elements of Power: Guns, Gadgets, and the Struggle for a Sustainable Future by David S. Abraham, which describes the processes by which rare earths and other metals travel from various mines to some of our everyday technologies. Although Abraham still relies on the mischaracterization of certain metals as "rare," he insightfully noted: "It's not hyperbole to state that the fate of the planet and our ability to live a sustainable future ... depends on our understanding and production of rare metals and our avoidance of conflict over them" (2015, xiv). The key point here is that it is not the elements that pose the danger, but how we source and consume them. Given these high stakes, it is unfortunate that so much fiction abounds. ${ }^{4}$

The first step to understanding the politics surrounding rare earth elements is getting the story straight. Rare earths are not rare. Abundant geological and mineralogical research shows that we are nowhere near exhausting Earth of potential mining sites, for rare earths or otherwise. If we are interested in resolving rather than aggravating the contentious politics surrounding rare earth mining and processing, we need to understand why certain places have emerged on the global rare earth frontier in the first place. Despite the abundance of post-2010 books on the topic, fundamental questions remain wholly or partially unanswered: What, precisely, are rare earths, how did they come to be so important, and why, 
given their relative ubiquity in Earth's crust and overwhelming importance to everyday life, is the geography of their production confined to so few places?

This book answers these questions. It investigates the global geopolitical superstorm raging around rare earths by diving into several of its constitutive cells, from the Mongolian Steppe to the High Amazon to the Moon. This is, first and foremost, a work of geography-literally, "writing the world." Geography is concerned with how particular spaces are produced by people interacting with the environment in specific times and places. In this approach, nothing is a priori or determined, but rather, written into being through a host of interacting, aggregate, and (un)intentional actions unfolding over time. There are no "externalities" in geography: the very word "externality" reflects a way of thinking that does not match reality. As residents in an integrated biophysical Earth system, there is no part of the Earth that is external to our affairs. Pollutants do not respect boundaries, nor do our efforts to acquire the elements essential to contemporary life. In geographical research, the biophysical, historical, political, cultural, and economic dimensions all matter. Lave et al. (2014) put it best with the statement that "specific modes, strategies, and institutions of governance and development interact with stochastic, contingent physical processes to shape the earth; racism, the movement of global capital, and the history of colonialism are as fundamental as the hydrologic cycle, atmospheric circulation, and plate tectonics" in producing the present (7). Such an approach is both explicitly political and deeply attuned to environmental conditions: if we eschew facile determinism, then we can see that much that defines our contemporary world is of our own making. To a far greater extent than we might generally acknowledge, we are responsible for the outcomes of our actions in a world defined by tremendous diversity and possibility.

This is no less true in a socially necessary enterprise such as rare earth mining. It may seem strange that the sourcing of the elements on which contemporary life depends is characterized by unusual geographies of production. It may even seem paradoxical that mining the elements so necessary to our greenest and greatest technologies generates immense environmental and epidemiological devastation. Such a situation is far from natural or inevitable, but how we arrived at the crisis of 2010 and what continues to drive the strange geography of the global rare earth frontier can be historically understood. When we take history and politics into account, we see that the geography of the global rare earth frontier is geologically contingent, rather than geologically determined. Hence the present work examines how the global rare earth frontier, in selected diverse places, is written into being by specific actors, events, and institutions. And how, in these remote places, rare earths sometimes serve as a mere pretext for broader geopolitical and economic struggles. 
If we are concerned with sourcing rare earths in a manner that is not only more reliable and less crisis-prone but also socially and environmentally just, then we must first understand what it is that drives production to certain places. Navigating this far-flung terrain requires a grounded approach. Thus the book begins with the first chapter devoted to the deceptively simple question: What are rare earths? In addition to their defining role in contemporary life, rare earths are also heavily mythologized. Myths serve a purpose: propagating narratives, norms, and forms of social control. To unpack rare earth myths in their local forms at several points across the globe and beyond, I examine the local landscapes and transnational histories with which rare earths are literally and figuratively intertwined and from which the myths draw their potency. This book is therefore about much more than the elements. It is about the way they are given meaning, and how those meanings reconfigure space in specific far-flung places. The actual spaces to which these myths are addressed are those over which their propagators seek control. This is the frontier space, defined in the next section.

In light of the indisputable importance of rare earths and the abundance of accessible deposits, the scattered geography of the global rare earth frontier cannot simply be taken for granted, attributed to geological determinism or the "free hand" of the market. Chapters 2 and 3 examine how and why China's Bayan Obo mine in Baotou, Inner Mongolia Autonomous Region emerged as the single greatest source of rare earth elements worldwide, showing that neither China's grand strategy nor Western lassitude provide sufficient explanation for our present global arrangements, as has been repeatedly alleged. Chapter 3 delves into the local environmental and epidemiological problems in northern China that prompted the change in China's political economic priorities from export dominance to conservation. Chapters 4, 5, and 6 follow the ramifications of these shifts as they unfold across several - but certainly not all — new sites on the global rare earth frontier.

The contemporary global geography of rare earth prospecting and mining is of course linked to the story of China's contemporary dominance in rare earth exploitation in particular, as well China's global integration and attendant geopolitical developments more generally. But this is not simply another story of how China might be taking over the world. In order to identify what drives our destructive and conflict-prone practices of sourcing rare earths, this analysis goes deeper to investigate the particular dynamics at work in three types of sites: established, explored, and prospective. The established site is China's Bayan Obo mine in Baotou Municipality in Inner Mongolia Autonomous Region, which borders Mongolia to the north and is the source of roughly half of all rare earth elements consumed worldwide. The explored but unindustrialized site is São Gabriel da Cachoeira, the northwesternmost municipality of Amazonas state in Brazil, which borders Venezuela to the north and Colombia to the northwest and holds 
some of the highest concentrations of rare earths identified to date. The prospective site is located on the western lunar highlands, on the Moon, which is currently enshrined in robust international treaty regimes as the indivisible patrimony of all humankind. As presently discussed, each of these sites exemplify the (un)making of the frontier by connecting the political economy and political ecology of rare earths to territorial contests preceding and emergent from the 2010 crisis. To support the in-depth analysis of each of these sites, several others are briefly discussed throughout the book (see figure 2).

Although this analysis is global in scope, it is not exhaustive. Rather, it delves into the multilayered significance of rare earths, exposing their roles in everyday life and exploring how they illuminate ongoing territorial struggles in some of Earth's most iconic places. The emergence of Baotou, São Gabriel da Cachoeira, and the Moon in particular as key points along the global rare earth frontier cannot be explained by mere accidents of geology or exercises of economic rationality. This is precisely what makes these sites key to understanding contemporary strategic resource geopolitics: by examining the dynamics that brought these three far-flung places into the global rare earth frontier, we can identify some of the more intractable obstacles to sensible sustainable resource use globally.

Therefore this work is structured around an inquiry into the spatial politics with which specific rare earth deposits are entangled at local, national, and international scales in Bayan Obo, São Gabriel da Cachoeira, and the Moon to explain why these specific sites have emerged on the global rare earth frontier. Spatial politics are concerned with the concrete, material processes of (re)production, power, governance, and everyday life that define human-environment relations within and across specific places. ${ }^{5}$ This inquiry is concerned with precisely which practices, ideas, and environmental factors shape our global arrangements of rare earth exploration and production. To wit: Through what processes were the deposits at Bayan Obo transformed into the single greatest contemporary source of rare earth elements worldwide? What local material conditions prompted the shift in China's production priorities from export dominance to becoming a net importer? How has this ramified across the global rare earth frontier? Specifically: Toward what end is the Brazilian government undoing its own indigenous and ecological protection laws to mine São Gabriel da Cachoeira, a historically contested border region shared with Venezuela and Colombia, when there are more easily accessible deposits under production in existing mining sites elsewhere in the country? And why have NASA and the US Department of Defense chosen to partner with Silicon Valley start-ups to mine these elements from the Moon, while the United States throws away hundreds of tonnes of rare earths annually in mine tailings and e-waste?

All of these questions are posed at the intersection of specific local and broader global processes, thus conceived in order to illuminate contemporary rare earth 
politics the way a lighting strike reveals, for an instant, the shape and order of myriad things whipping about in the darkness and confusion of a superstorm. No storm is caused by the wrath of the gods-we need not be mystified by them. Nor should we be mystified by the state of global rare earth politics. They emerge from discernible and knowable phenomena that, if understood, can inform reasonable action despite perpetual fears of impending crisis or prognostications of "mineral eschatology" (Bardi 2014, 241). Conversely, if storms are left to the stuff of myths, if we take the fear and hyperbole surrounding rare earth elements at face value, then any number of fictions of impending disaster might be leveraged to force people to accept things they would otherwise quite sensibly reject. By demystifying rare earths and laying bare the operations of the global rare earth frontier in specific places, this book takes aim at those who would have us undo hard won progress in environmental and social protection and peaceful international cooperation in the name of impending resource apocalypse.

There are two short answers to the series of questions posed above. The first is that mining these places is about more than rare earths. It is about demonstrating, through high-tech militarized means, the capacity to stake a claim to historically contested and geopolitically significant spaces rather than about the actual practicalities of establishing mining operations. As the history of Bayan Obo illustrates, the ethno-national and geopolitical ends served by establishing mining operations in a hostile and historically contested terrain justified the immense multinational undertaking to build an industrial base on the southern Mongolian steppe. The second answer is perhaps more fundamental: the social and environmental hazards involved in producing rare earths exert an outward (or inward, depending on your perspective) pressure on the placement of rare earth mining and production. The twin desires to isolate the hazards while capturing the geopolitical benefits of keeping the production of these strategically vital elements within a particular set of borders drives production to the frontiers of empire, state, and capital.

This tension explains why the rare earth frontier is found in borderlands and hinterlands, in places where local landscapes and lives are deemed sacrificable in the name of some greater good (Campbell 2000; Hecht 2005; Johnson and Lewis 2007). The "greater good" refers to the utilitarian principle in economic, politi$\mathrm{cal}$, and philosophical discourse that views the best possible outcome as whatever brings the greatest possible benefit for the greatest possible number of people. This principle is often used to justify some measure of harm or sacrifice concentrated somewhere. These places where the toxic enterprises and their ill effects ultimately land are known as "sacrifice zones" because their destruction is considered indispensable to achieving the greater good. Sacrifice zones are where the so-called negative externalities are located. They are not ephemeral or intangible: they have a 
specific geography that can be mapped. The destruction of landscapes and lives in pursuit of rare earth mining has generally been considered a fair price to pay, generally by those who do not live in the sacrifice zone.

The greater good operates transnationally to temporarily resolve the otherwise impossible tension in which rare earths must be procured by industrialized countries, but for which very few wish to assume the risk of extracting them from their own subsoils or investing in greener production practices. This tension also drives the dynamism of the global division of toxic labor, which is never settled, but resolved only through periodic fixes as toxic industry moves from place to place, seeking out new locales where local landscapes and lives are imagined to be worth less. As shown in subsequent chapters, Euro-American production migrated almost entirely to China by the late 1990s, following a series of extensiveand expensive-environmental disasters at Western production sites. Over the first decade of the twenty-first century, as ecological and epidemiological crises deepened in China's rare earth mining regions, the central government formulated a long-term policy portfolio aimed at shifting the country's position from a net exporter to net importer of basic rare earth commodities. This domestic fix operates by driving the environmental burden of rare earth mining and processing beyond China's borders through multiple trade, investment, and aid partnerships. Efforts to transnationalize China's rare earth hinterland do not end there. Seizing on the inability of the global market to support greener rare earths, private sector firms and military planners across the globe have leveraged scarcity myths to advance a campaign to enclose outer space resources.

Neither the price nor the actual availability of rare earth elements is sufficient to explain such extreme measures. While there is a clear need to isolate and contain the toxic wastes generated by rare earth mining and processing, the strange geography of the global rare earth frontier is driven by the desire to capture the geopolitical benefits of establishing rare earth production in certain places. This is a key feature of our contemporary global arrangement of rare earth production, which must be examined in global perspective so that we might identify workable global solutions. Toward that end, this investigation uncovers shared historical experiences across vast distances that have, until now, been overlooked due to entrenched Orientalist and Cold War-era assumptions that "East" and "West" are mutually unintelligible. The fact that a compelling link between Inner Mongolia and Amazonas, or between extractive frontiers on Earth in outer space, might seem far-fetched or counterintuitive highlights the limits of the received wisdom with which we seek to understand contemporary global issues.

In fact, Bayan Obo, São Gabriel da Cachoeira, and the Moon have much in common. They are each frontiers for the extractive aspirations of states and empires, and they are each current and historical sites of struggle against the impo- 
sition of sacrifice or destruction. While their geological endowments provide some logical basis for their potential as mining sites, this is not sufficient explanation for their emergence on the global rare earth frontier since there are so many other less controversial, or at the very least, operational sites around the world. Were the global geographies of rare earth prospecting and mining the mere result of the practical organization of global resource provision, Inner Mongolia, the Amazon, and not to mention the Moon, would be unlikely sites. Instead, they are definitive of contemporary global resource geopolitics, in which geographies of extraction are dictated by racially charged territorial ambitions intertwined with geological and economic circumstance.

In these three instances separated by immense spatial and temporal distance, the production of geological knowledge has been used to advance broader colonial, imperial, national, and private sector projects to control the landscapes and lives under which rare earth deposits are situated. For decades, even centuries, conflicting land use regimes and competing claims over local resources thwarted large-scale mining operations. In each of the sites examined herein, frustrated territorial ambitions leveraged broader shifts in global resource geopolitics to frame mining rare earths as vital to some greater good, whether that is defined as national development, economic security, or all humanity. In short, Baotou, São Gabriel da Cachoeira, and the Moon emerged as key points along the contemporary rare earth frontier in part because they had been frontiers of another sort, and continue to pose a frontier problem to multiple territorial powers.

\section{What Is the Frontier?}

We cannot begin to understand our present rare earth situation without critically examining the sorts of spaces in which rare earths are mined: frontiers. Precision is necessary when invoking the term "frontier." As a spatial, temporal, cultural, political, and scientific signifier, the word is used so broadly that it must be carefully defined to serve any useful analytical purpose. There is a sense in which the frontier is an ideation, or used figuratively to convey a sense of civilizational progress, as in the frontiers of research or technology. But even these figurative uses bear implicit spatial politics: the actions taken to reach an imagined or figurative destination are material, and therefore place-based and spatial insofar as they involve specific people and resources. The frontier is also used literally to refer to a place, whether that place is an ambiguous zone or a Cartesian line. Such places are also ideations, but they are ideations to which people give meaning through enforcement mechanisms in specific places. A frontier always refers to a real and imagined place that is specific to times, places, and cultures in which they are 
invoked. In both literal and figurative senses, frontiers change over time. In this book, the frontier refers to the more or less vaguely specified zones over which multiple actors and institutions compete for control, both over the place and over the extraction of its strategically valued rare earths. Secondarily, the frontier refers to the manners in which such places are described, imagined, and problematized.

These dialectical characteristics of the frontier-literal and figurative, real and imagined, material and meaningful—are co-constituted with the exercise of state and corporate power. Most basically, the frontier implies a limit: the limits of state power and rule of law, of the known and disciplined, and of a set of particular social relations or identities. Therefore the frontier narrative, when invoked, represents a set of spatialized intentions to transform a place that is unknown and ungoverned into the known and disciplined: to penetrate the impenetrable, to transform untapped minerals into wealth and power. For our purposes, the use of the term implies a project to turn the space in question into something else. The desired outcome of that project is to enclose the space containing strategically valued resources. The act of enclosure transforms that space from a frontier beyond the reach of state or corporate power into a hinterland, the (re)productive activities of which are reoriented from sustaining local economies to enriching extralocal actors. Thus frontiers are not objective facts existing in any a priori sense. The frontier is conjured in order to be spectacularly destroyed (Tsing 2005); its environments mythologized in order to be pillaged or policed; its inhabitants exoticized or dehumanized in order to be minoritized or murdered.

A conspicuous feature of this project is the tendency on the part of extralocal actors-states, firms, strategists of all kinds- to view frontiers as zones of legal ambiguity or lawlessness (Evans 2009; Haynes 2014). While this is sometimes the case, it can also be the case that local social relations, property regimes, and governance structures, by virtue of being independent of or contrary to the ambitions cultivated in distant metropoles, are simply ignored by state, corporate, or imperial agents. The reason for this is straightforward: accumulation by extralocal actors cannot occur if those same actors do not possess orchestrative control over the land, property relations, and authoritative institutions local to particular resources.

In mining sites, the contradiction between local livelihoods and extralocal impositions is absolute. Minerals are for the most part located beneath the surface. Large-scale mining operations cannot proceed without annihilating the landscapes and lives atop the deposits, which is an activity of such upheaval that it requires the exercise or invocation of legal exceptionalism in order to proceed. Therefore the frontier represents both a limit and a possibility where the exercise of extraterritorial, extrajudicial, and extraordinary state power is concerned. By expressing a limit, the state, corporate, and military actors can conjure a space in which power can 
be exercised with fewer restraints. Hence, as the diverse cases in this book show, the frontier narrative reconstructs local identities as underdeveloped, unproductive, or even nonexistent for the purpose of extralocal exploitation.

But there was always a before, a time when local landscapes and lives were not pathologized in a frontier narrative. This is true for the sites comprising the global rare earth frontier, even those beyond the scope of this book. Frontiers are often imagined as empty of (indispensable) people yet full of the particular variety of riches fancied by extralocal actors. For example, to early explorers and planners, Bayan Obo was a "wasteland"; for centuries, surveyors, missionaries, and federal officials described São Gabriel da Cachoeira as "the end of the world"; the Moon has become, to aspiring miners and colonizers, "a treasure trove" that "belongs to no one." But such imaginings are false. Where the sites are not populated with communities, they are filled with collectively held significance. The key is that spaces must be literally or discursively made empty in order to be coherently reimagined as a frontier.

Therefore the frontier project is supported by forcefully enacting a reality that matches the narrative. Erasing or problematizing local territorial orders whose very existence contradicts the frontier narrative becomes the first and ongoing order of business. A territorial order refers to the social organization of the landscapes and lives rooted in a particular place. As people build their lives, they transform the spaces in which they live according to collective social logics: they build and sustain territorial orders such as villages, productive ecosystems, or cities. People do not exist without territorializing space, without making it into something that supports their existence. To (attempt to) erase these deep social logics is not just a matter of "impacting" local populations, but also of transforming the landscape. In critical social theory, this (attempted) erasure is known as deterritorialization (Deleuze and Guattari 1987). What follows is not empty space but a new territorial order. Reterritorialization is the (attempted) imposition of a new order, which necessarily follows deterritorialization as two aspects of connected yet spontaneous processes. The preceding territorial order cannot be wholly or partially destroyed without another order taking its place, even if that so-called order is violent disorder.

Once deterritorialized, frontiers can be reconstituted by the state, reterritorialized through settlement campaigns, infrastructure construction, or military fortification. Ambiguous zones can be carved up with borders and zoning ordinances to remake frontiers into the hinterlands from which the "cores" draw their resources (Lefebvre 2009; Pomeranz 1993). The purpose of imposing a border is to assert a sovereign claim over a given space and the resources therein, while the purpose of zoning is to orchestrate local (re)productive activities according to broader governance objectives. Borders represent inward assertions of the 
physical boundaries of "imagined communities" (Anderson 1982) and outward assertions of geopolitical power. In the case of commercial mining enterprises, a clear border and an exclusive zone are essential to securing investments. Ambiguous zones are the bane of nation building and commercial enterprises alike, therefore imposing borders is a critical component of the frontier project insofar as it represents an effort at greater precision: the frontier may be a vaguely specified zone, but the border is a line. Commercial forays into new spaces rely heavily on the force and backing of the state to maintain conditions amenable to exclusive large-scale extraction. The very absence of borders in "the final frontier" is a central problem for private outer space mining enterprises, which have enlisted the expertise of legal scholars since the mid-1990s in order to formulate a propertyrights regime for the privatized exploitation of lunar resources (Al-Rodhan 2012; Lewis 1996).

Because both frontiers and borders tend to be produced through a gaze from elsewhere, their very production is an act of both incorporation and peripheralization. By imposing a border, people and places are simultaneously zoned into (or out of) the national geo-body (Winichakul 1988) and also placed at its periphery. Hence the boundaries between (un)known and (un)governed tend to cleave along racial and cultural lines. The project of concretizing this line in the form of a border generates ambiguities and violence as competing sovereignties are divided or suppressed.

In the northwestern Amazon as well as on the Inner Mongolian Steppe, the history of border-marking and resource extraction has been "written in blood" (Mote 1999; Pinheiro 1995), characterized by struggles between Euro-Brazilian and Han Chinese colonizers on the one hand, and indigenous peoples on the other. As the cases of China and Brazil show, it takes multiple generations of violence and massive in-migration campaigns to inculcate a frontier subjectivity in local inhabitants. The "frontier subjectivity" refers to that profoundly alienated sensibility that the native soil on which one stands is somehow distant or peripheral as well as fundamentally different from the soils nearby, occupied by one's kin, but nevertheless on the other side of the border. This cognitive-cultural sleight demands that local inhabitants reconceptualize their local territorial orders as anachronistic and subjugated to a larger territorial order, defined in the cases of São Gabriel da Cachoeira and Baotou according to the priorities of a distant yet locally proliferated central state.

An ideal frontier subject is sufficiently self-reliant to minimize state obligations to the local population, but sufficiently dependent on the state so as not to directly challenge state sovereignty. Understandably, people tend to resist or redefine the imposition of such a condescending subjectivity. It is atop deep histories of contestation that rare earth reserves have been be framed as part of the 
national patrimony in China and Brazil, while on the Moon, where assertions of national sovereignty are forbidden, resource exploitation is framed as a necessity for "all humankind" (Moon Express 2013). The invocation of national collective interest is hardly peculiar to rare earth extraction; the justification for sacrificing local landscapes and lives is consistently framed in terms of a "greater good" in extractive and other toxic enterprises (Fox 1999). But as the cases examined herein show, extralocal actors tend to define the greater good according to extralocal interests. Livelihood activities that inhibit state coercion of local groups, such as small scale, informal, or family mining enterprises, are criminalized. Generally, when commercial large-scale mining is framed as essential to the nation, artisanal or clandestine exploitation is framed as a crime against the citizenry (as in China), or as evidence of an ineffective state (as in Brazil).

Like frontiers and borders, the hinterland designation implicates a vantage point from elsewhere: if not a self-proclaimed center, then an urban or commercial space. As populations condense within (sub) urban centers of spectacular consumption, glittering with flat screens, ringing with smartphones, surveilled with evermore sensitive technologies, and ensconced within durable steel-alloy architecture - all of which depend on rare earth elements - the land and resource area needed to sustain high-technology consumption expands. Resource hinterlands are not contiguous features of metropoles: they are defined by their distance, measured in miles and otherness, from those who claim to uphold the center of human civilization. They are scattered across the globe and beyond, driven by that fundamental tension between the need to sequester the hazards of mining and processing as well as the desire to capture potential economic and geopolitical benefits associated with controlling rare earth production.

This tension defines the global rare earth frontier. For each site that could be included in an exhaustive global catalogue, there are stories of enclosure, contestation, and violence as states and firms work to confine the hazards of mining and processing in places deemed sacrificable to the greater good of rare earth production. The case of Australia's Lynas Corporation, Ltd splitting its operations between mining Mount Weld in Australia and ore processing in Kuantan, Malaysia is a case in point.

The Mount Weld deposits were discovered in 1988. In 2001, the twenty-yearold gold mining company, Yilgangi Gold NL, sold off it gold division and rebranded itself as Lynas to focus on developing this particular rare earth deposit following the closure of what had been the last remaining rare earth mine outside of China: the Mountain Pass facility in the United States (discussed in chapters 1 and 4). For several years, Lynas worked on raising capital to develop the deposit.

In 2009, China's State-Owned Non-Ferrous Metal Mining Group offered to purchase a controlling 51.6 percent stake in the company. Australia's Foreign 
Investment Review Board blocked the transaction (Bloomberg News 2011). Later that year, the company received approximately $\$ 330$ million from JP Morgan to keep the company afloat by inducing Australian and New Zealand shareholders to purchase additional shares ${ }^{6}$ (Lynas Corporation 2009). In the heat of the late 2010 tensions between China and Japan, Lynas signed an agreement with Sojitz, a Japanese rare earth trading company, to export three thousand tonnes to Japan beginning in late 2011 (Tabuchi 2010). Meanwhile, the company worked to open the offshore Lynas Advanced Materials Processing (LAMP) facility in Gebeng, Kuantan, Malaysia. Former CEO Nicholas Curtis explained the site selection as a matter of good business. The Gebeng Industrial Estate is a Malaysian state-owned initiative designed to attract chemical industries to an area with robust industrial infrastructure, abundant water, and a skilled, lower cost workforce. According to company press releases, locating the processing facilities in Malaysia would be good for the company, and good for Malaysia's economic development.

Local residents and officials disagreed on several counts. First, a twelve-year tax break offered to Lynas meant the Malaysian government would not collect revenues from the operation for the foreseeable future. Second, residents, officials, and observers were alarmed at reports of structural and engineering flaws in the facility (Bradsher 2011b; Butler 2012). Galvanized by the cancers and birth defects suffered by workers and community members at the Japanese-run Bukit Merah Mitsubishi rare earth processing facility in the 1980s (Consumers Association of Penang 2011), an international coalition organized under the banner of Stop Lynas Save Malaysia (2014) to halt construction of the LAMP facility. As protests peaked in 2011 and 2014, the Malaysian police imprisoned demonstrators from Malaysia, Australia, and New Zealand (Bradsher 2011b; Davey 2014a, 2014b; Lee 2011).

Despite public outcry, validated in part by findings published in a June 2011 report by the International Atomic Energy Agency (IAEA) concerning inadequate waste disposal and containment measures, the facility became operational in 2012. The company reports that it is meeting all of its environmental and safety requirements (Lynas Corporation 2016), while mining researchers, investors, and officials in Australia and Malaysia characterize public concerns as disproportionate to the actual levels of radioactivity contained in the ores brought to the facility (Ali 2014; Matich 2015). International environmental activists countered that if in fact the materials are so safe, the wastes should be reimported to Australia for value-added processing there. The Australian government refused to accept any responsibility for waste material produced by Lynas' Malaysia plant. Western Australian Minister for Mines and Petroleum, Norman Moore, stated "national legislation stipulates that Australia will not accept responsibility for any waste product produced from offshore processing of resources purchased in Australia 
such as iron ore, mineral sands, and the rare earths produced by Lynas Corporation" (Sta Maria 2012). The IAEA follow-up report in 2014 found that many of its recommendations presented in 2011 had been wholly or partially satisfied, but recommended greater monitoring and transparency concerning the ecological and public health effects of radioactive effluent in the Balok River and other bodies of water (IAEA 2015).

While public pressure was insufficient to prevent onshoring some of the more hazardous aspects of rare earth processing in Malaysia, it has been crucial in drawing attention to the need for greater transparency and accountability in the sourcing of rare earth elements. In 2015, the new CEO of Lynas, Amanda Lacaze, moved to Kuantan to oversee the operation more closely. A celebratory May 2016 celebratory piece in The Australian reported that Lacaze's husband currently does local charity work for disabled children in the community while she turns "a company heading for collapse into an efficient, viable business" (quoted in Korporaal 2016, 21). The case of Lynas can be, and has been, analyzed as one of environmental violence enacted by an Australian company on the peoples in the developing country of Malaysia. Opponents to the LAMP facility argued repeatedly that Malaysian lives were as important as Australian lives (ABC Radio Australia 2014). It has also been described as a straightforward cost-savings measure undertaken by former CEO Nicholas Curtis who wished to take advantage of the industrial capacity, cheaper skilled workforce, and access to abundant water and regional markets afforded by the Malaysia location. Whether the driving factors are understood as environmental racism or simply smart business, the central issue has been the spatial allocation of sacrifice and the management of the harms generated by rare earth processing. In this case, differing social and regulatory thresholds scattered the rare earth hinterland between Australia and Malaysia, between a developed and a developing country. During its brief revival in 2012-15, the US Mountain Pass mine resorted to similar measures, discussed in chapter 3.

Where the matter is not primarily the spatial allocation of sacrifice, the geography of rare earth mining and processing is driven to some places and not others by the desire to extend corporate, national, or imperial power. In some cases, building an industrial mining operation serves as a method of territorial control. Rare earth ventures in Afghanistan and Kyrgyzstan illustrate this point. The Ak-Tyuz mine is located in the northern Tien Shan Mountains in Kyrgyzstan and was opened by the USSR in 1942. This was an important source of strategic elements - from antimony to rare earths and uranium - for the Soviet military industrial complex through the late 1970s (Djenchuraev 1999). Construction of the facilities at Ak-Tyuz was part of the larger project of incorporating new territories by developing military-industrial bases in Soviet republics and satellites across inland Eurasia. The broader objectives were to quite literally build a world 
communist empire directed from Moscow. As detailed in chapter 2, the Baotou facility was also built with extensive Soviet support under the aegis of provisioning the world communist revolution.

In post-Cold War, post-9/11 Afghanistan, the territorial dividends of establishing industrial rare earth mining and processing complexes have caught hold of the imaginations of some planners and geologists among the US-led forces still operating in the country. Chapter 4 discusses the Coalition Forces' promotion of rare earth deposits in Helmand, the Afghani province with the greatest opium production, highest volume of refugee flows, and strongest militant presence, as an "exciting" investment opportunity for an "enterprising company" (Coats 2006; Tucker 2014). The extensive efforts around the globe-from southeast China and India to Afghanistan and the Amazon - to criminalize or eliminate artisanal mining further demonstrates that only certain forms of extraction are welcome on the global rare earth frontier. Aside from the risks faced by miners of direct exposure to the hazards of small scale mining and processing, which states have a history of tolerating for economic and political reasons, ${ }^{7}$ the primary issue is that small-scale operations are very difficult for national governments to tax. As in the cases of Brazil, Colombia, and Afghanistan, where revenue streams sometimes support groups with territorial claims contrary to existing governments, smallscale mining is an important source of autonomy.

Each rare earth mining site, past and present, is worthy of its own book. No two sites are identical in history, geology, technology, or in the social organization of extractive labor. The present work is not concerned with cataloguing all the rare earth ventures in the world, but with examining the role of rare earths in nation building, geopolitical contests, and global political economy in world historical perspective. As noted, this is done by examining an established, an emergent, and a prospective mining venture, and inspired by renewed awareness of our dependence on these elements. The broader appreciation of the importance of rare earth elements has not, however, rendered production and consumption more rational or sustainable. This suggests that a more complex and intractable set of spatial politics are at work.

If we look at rare earths devoid of their spatial politics, we see naught but a market mysteriously dominated by China and a few other minor players. If we look at only a few rare earth frontiers devoid of their world-historical contexts, we risk reinforcing certain (post)colonial assumptions that some people and places are simply more appropriate for waste than others. Or, denying such racism, we risk relying on facile geological determinism. Such analyses are not only despatialized and ahistorical, they are also dehumanized. This is why it is important to study the global rare earth frontier in its historical and political complexity: to make sense of where, how, and why diverse actors and institutions across 
the globe continue to invest in a destructive and crisis-prone system of production to sustain the globally integrated life most of us know today. We must understand where, precisely, the elements of everyday life come from, and what places, people, and struggles are involved in producing this state of affairs.

Therefore further precision is necessary when referring to the global rare earth frontier that is the topic of this book, because there is a sense in which rare earth-enabled innovations drive the frontiers of everything: technology, consumerism, surveillance, warfare, postpetroleum possibilities, human exploration of subatomic and outer space, and indeed, contemporary geopolitics, power, and accumulation. The term "global rare earth frontier" could, and should, refer to the multiple sites and situations in which rare earth elements are used; where researchers engage in concerted efforts to force technology beyond current limits of possibility; where ores are processed and to what extents toxic by-products penetrate surface and subsurface environments as industrial run-off; how we incorporate rare earth-bearing products into everyday life in evermore intimate and mundane ways; and where these products land when the larger machine of which they are part is discarded as waste. These questions cry out for further research. This present work is concerned with three primary and several secondary examples from the frontier that is fundamental to all others: the mined and tobe-mined.

The central drivers of this frontier process are evolving sets of geological knowledge about particular rare earth deposits that have been vested with strategic significance. Not just any deposit- there are, after all, hundreds scattered across the globe-but those defined as strategic by state, military, public, and private actors in order to reorganize the surrounding environs.

This lies at the heart of the geopolitical projects driving the geography of the global rare earth frontier, masquerading in context-specific discourses of security or development. Two valances of geopolitics are useful here: conventional and critical. Conventional geopolitics are concerned with the balance of power among states, for which exercising orchestrative control over an internationally recognized territory is a precondition for enforceable sovereignty, and as noted above, necessary for industrial extraction to proceed. For China, Brazil, and other state actors in the contemporary rare earth game, erstwhile desires for (inter)national power and recognition have been pinned to gaining control over a critical share of rare earth production by exploiting a problematic place. Transforming regions that have historically evaded state control into mining and industrial hinterlands serves important geopolitical purposes of disciplining historically autonomous regions and projecting power internationally.

There is, of course, more to the story. While useful, conventional conceptions of geopolitics have limitations: they can fall into the "territorial trap" (Agnew 1994), 
which occurs when states are taken as primary actors in international affairs, rather than examined as one set of nodes in a network of multiscalar social relations. Such approaches often assume that power is organized in discreet national containers, which erases differing interests within states and ignores common interests across transnational space. Representing nation states as discreet monolithic entities must be treated as such: a representation that, however compelling, is fundamentally different from the complex realities unfolding on the ground. Taking the simplifications of state discourses at their word limits the extent to which conventional geopolitics can help us understand the global rare earth frontier.

The second valence, that of critical geopolitics, is concerned with "examining politics at scales other than that of the nation-state; by challenging the public/private divide at a global scale; and by analyzing the politics of mobility" (Hyndmann 2001,210). This book examines the state as one of many actors working at multiple scales to mine impossible places. Accordingly, how private enterprises and public oversight mechanisms are differentiated is interrogated rather than taken for granted in each of the sites. The public/private divide is a legal artifice and a historical contrivance whose precise definition varies across time and space. Legally, it is used to orchestrate state jurisdiction over the actions, resources, and (re)productive capacities of people and firms in a selective designation of what is subject to public oversight, and what falls within "a separate private realm free from public power" (Horwitz 1982, 1424). Historically, the public/private divide refers to the violently enforced difference between paid and unpaid labor. Because reproductive work is historically devalued, considered a private matter and gendered female, the public/private divide is gendered (Federici 2004). Where the Westphalian state has consolidated power, this has historically translated into marking men and women respectively as legitimate and illegitimate agents of political economic life. This division of labor in society does not stop at gender. Such a division is also characterized by the imposition of racially coded difference between hegemonic self and subaltern "ethnic" other (Guillamin 1995), with its spatial corollaries of core and periphery, capital and frontier, metropole and hinterland, the "right" and "wrong" side of the border. These raced and gendered divides are manifest in practices of extractivism. "Ethnic" women engage in much higher numbers in artisanal operations that are more vulnerable to expropriation and criminalization. Conversely, men are over-represented in industrial mining enterprises that proceed at the behest of the state. The manner in which multiple actors invoke rare earth mining and prospecting as a matter of national significance contrary to competing local interests is an object of analysis because it shows how the frontier project works to redefine notions of accountable public rights and unaccountable private matters. The content of public/ 
private categories shifts over time and space while the medieval fiction of the divide between the two remains instrumental to geographies of extraction, production, profit, and sacrifice.

The lens of critical geopolitics allows us to see that the rare earth frontier cuts literally and figuratively across human bodies. How we organize the risks and benefits of rare earth production across space-and the inevitable measure of destruction that entails - is intricately interwoven with (un)conscious evaluations of the worth of some human lives relative to others. Which people incorporate the sacrifice zone into their bodily tissues is not a matter of random happenstance. These evaluations are riddled with raced and gendered notions of difference, where some landscapes and lives are considered more expendable than others. The intimate politics of sacrifice assume many forms: uprooted communities, the impositions of gendered labor practices at production sites, the shortened lives and miscarried pregnancies that result from prolonged exposure to the air, soil, and water contaminated by rare earth industries.

None of this is to suggest that possessing certain markers of privilege is sufficient to protect an individual from the toxic effects of rare earth production. However, it is notable that in the primary cases examined herein as well as several others beyond the scope of this book, those setting out to conquer the rare earth frontier are vested with multiple forms of power-including relatively privileged race, class, and/or gender power-over those who live atop the deposits or downstream from the processing site. That race and waste coincide, that poorer communities comprised of differentially raced or ethnicized "others" are disproportionately burdened with toxic industries and effluents is well established by hundreds of case studies from across the globe, revealed in research that has reinterpreted the past several centuries of global change (Bryant and Mohai 1992; Dillon and Sze 2016; Harvey 1996; Merchant 2003; Pulido 1996). The distribution of harms generated by rare earth mining and processing is not exempt from broader historical practices that sort labor and sacrifice according to race, gender, and class.

These (un)intentional sorting mechanisms that shape the spatial politics of the rare earth frontier have not been resolved by legal measures. Legislative attempts to mandate greener, nonviolent mineral sourcing have had mixed results at best. Often, mining activities cannot be easily sorted into "legal" or "illegal" categories. There is a complicated coexistence between the two. Generally, the difference depends on whether a particular operation lends itself to taxation or other forms of surplus extraction. Much has been made of campaigns in both Brazil and China to crack down on clandestine mining and the black market mineral trade (Li 2017; Taylor 2016). This is not necessarily a new phenomenon, but rather an episodic censure of customary practices. In truth, mining companies have historically 
depended on artisanal miners to assume the risks of prospecting and exploration (Hecht and Cockburn 1990). Despite government and NGO initiatives in many parts of the world, contemporary downstream industries in practice do not discriminate between legally and illegally sourced materials-even those from known conflict zones-if the price is right. ${ }^{8}$ Therefore the abundance of illegally mined rare earths estimated to be in circulation ${ }^{9}$ is hardly novel or peculiar to the rare earth sector.

When considering issues of legality in resource extraction, it is crucial to heed critical legal geographers' call to view law as a set of "lived institutions and relations" in order to examine "how and why law works to perpetuate particular relations of social authority, power, exploitation and oppression" (Chouinard 1994, 415). Legal mining is often synonymous with corporate mining to the exclusion or attempted erasure of small-scale and artisanal mining. Within frontier narratives, artisanal mining is too often marshaled as evidence to demonstrate the putative backwardness or lawlessness of a given place. As a term that is meant to provoke or problematize, the frontier is necessarily a temporary signifier, invoked precisely because it is meant to be transformed, for our purposes, into an enclosed rare earth hinterland from which the rest of the world might draw these essential elements.

The particular geography of rare earth mining and prospecting is not a straightforward matter of meeting global needs. The persistent myth of rare earths' rarity skews their politics and possibilities, reviving bold, even mercenary, mandates to explore far-flung and perhaps dangerous places in pursuit of treasure. ${ }^{10}$ Myths of rarity work together with the myths of the frontier: while the myth of rare earth scarcity may legitimate far-out prospecting activities, the frontier signifier works to recast a given space in terms of riches to be captured and a problem to be solved, regardless of what may already be there. Hence rare earths entangle with broader territorial ambitions to conquer all manner of frontiers so that one myth drives the other in service of territorial control and accumulation. Without a historically informed analysis of why certain unlikely sites emerge and persist on the global rare earth frontier when there are hundreds of known deposits, and hundreds of ventures to exploit less remote sites have failed, we cannot formulate meaningful proposals for a more just and sustainable production paradigm.

\section{The Primary Sites}

Naming a place a frontier recasts its qualities as problems requiring a certain kind of intervention. Baotou, São Gabriel da Cachoeira, and the Moon have been frontiers many times over, for many purposes, among them the construction of 
colonial and Cold War empires, the pursuit of collaborative international scientific research, and nation building in the name of development and security. The objectives of these various initiatives have been to rationalize space, to transform the unknown into the known. The rationalization of space is a social project: it is the ongoing project of states and firms to reorganize people and places in ways that serve extralocal governance and accumulation. In the cases examined herein, rare earth prospecting, mining, and processing serve these objectives in their contemporary forms.

Baotou, São Gabriel da Cachoeira, and the Moon respectively illustrate established, explored, and prospective aspects of the global rare earth frontier. Historically speaking, they reveal the historical, contemporary, and future-present of global development and resource geopolitics refracted through rare earth prospecting, mining, and processing. The historical processes through which these sites have been configured into key points along the global rare earth frontier are crucial to understanding contemporary global resource geopolitics.

Baotou was surveyed and territorialized by the contemporary state, and industrialized sixty years ago. By contrast, struggles in São Gabriel da Cachoeira and the Moon are unfolding as I write in anticipation of ramped up and regularized rare earth mining. This means that there were very different qualities and quantities of data available for each of these cases, which is reflected in the organization of the book. What is striking is that despite the enormous distances in time and space among these three frontiers, analogous and linked processes draw them into this common concern.

While the differences among the three sites are many and important, it must be said that the Moon is less unlike Baotou or Sao Gabriel de Cachoeira than one might expect. From the point of view of rare earth mining, at least, these distinctions primarily concern the technology required to bring the Moon within the purview of material engagement ${ }^{11}$ and to reduce transport costs. ${ }^{12} \mathrm{~A}$ further distinction is that the Moon is entirely unpopulated and is governed solely by international legal conventions, which prohibit claims of sovereignty or acts of enclosure. In this way, the Moon is similar to the deep seabed and the Arctic Circle, both of which figure significantly in global resource and territorial geopolitics (Macdonald 2007).

But from the point of view of rare earth extractors and attendant prospectors, territorial agents, and financial speculators, the commonalities between the Moon, Baotou, and São Gabriel da Cachoeira exceed the differences. No single mining site is exempt from the fundamental contradiction between extracting subterranean ores and preserving the landscapes and livelihoods unfolding on the surface. Even those sites inhospitable to humans such as the Moon or the ocean floor are imbued with competing valuations of the same space, whether it is scientific research or 
biodiversity and heritage conservation. This complicates discourses that describe the frontier as "empty." In many, but not all, populated sites, national and international norms now compel industry actors to exercise some form of social and environmental responsibility. This often means consulting "impacted" communities to define the terms of compensation for the obliteration of the lands on which their livelihoods depend, and/or seeking a "social license to operate" from those impacted communities. Although these forms of engagement are important, they remain problematic insofar as they are often a rehearsal rather than a deliberative forum, generally conducted by paid subordinates of the mining company whose job is to secure a minimal baseline of assent rather than determine whether the project should proceed at all.

As a multibillion-dollar industry, the move to drive mining off-Earth has gathered scientific and moral momentum precisely because of the assumption that there are no social or environmental hurdles to space mining activities. Such ventures are endorsed by ethical and scientific leaders such as Neil deGrasse Tyson ${ }^{13}$ and the Vatican Astronomer Brother Guy J. Consalmango. These developments demand that we look beyond our Earthly provincialisms that anachronously place the Moon and near-Earth outer space beyond the purview of global political economy and hence, of critical concern.

Many aspects of the frontier project that drove rare earth prospecting interests to Bayan Obo and São Gabriel da Cachoeira are operative with respect to the Moon as well. The technology and infrastructure requirements are perhaps the most apparent example of the temporal and technological relationality among these sites that emerge over time with changes in the global division of toxic labor. Bayan Obo was opened by rail and unpaved road built by mobilized migrant labor in post-World War II and postrevolution China. For mining to be feasible in São Gabriel da Cachoeira, reliable road or rail transport would have to be built, which has proven impossible over sixty years of campaigns to develop and integrate the Amazon into regional economies. For mining to be feasible on the Moon, transport costs would have to be dramatically reduced in order to bring elements back to Earth from outer space, so space-faring states as well as private firms are developing multiple strategies to creatively work around these costly logistical hurdles.

In each of the cases, the logistical challenges leading up to rare earth extraction require significant capital, expertise, and political will to overcome. The transport technology situations are indicative of the broader world-historical contexts in which these sites emerged on the global rare earth frontier. In other words, the contemporary global prominence of Bayan Obo is one outcome of postrevolution, postreform, and neoliberal development between China and the West since 1950. The contest over the future of exploitation of São Gabriel da Cachoeira is 
one aspect of shifts in the global division of toxic labor intertwined with Brazilian expansionism and geopolitical ambition as a major BRICS (Brazil, Russia, India, China, and South Africa) power, against which indigenous peoples seek to both maintain and modify statutory protections won in the last three decades. The latest race to the Moon is an outcome of four decades of neoliberal policies resulting in an immense concentration of wealth in the hands of an extreme minority, ${ }^{14}$ the subcontracting of state research and military operations to the private sector, and the resurgent geopolitical anxieties provoked by perceptions of intensifying resource scarcity dramatized by China's rare earth production and export controls.

In addition to these world-historical relationalities, there are several material and meaningful processes defining the sites respectively and collectively. Here, I highlight five specific points of comparison, selected precisely because they are so often framed in exceptional terms in the histories of each place.

First, as explored in-depth in chapter 1, these three sites share notable geological similarities. Elements of the crisis and the broader incidence of rare earth deposits may be fictive, but the basic dynamics of their geological formation are not. Rare earth deposits are formed during repeated cycles of small degrees of partial heating and cooling within Earth's mantle. This gradual process produces alkaline magmas which, when they ascend and cool in Earth's crust undergo further changes stimulated by local temperature, pressure, and chemical variations (Long 2010). Too much melting, or too rapid cooling, and rare earth deposits fail to coalesce. The deposits of both São Gabriel da Cachoeira and Baotou are situated along accretionary orogenic belts between major intracontinental cratons (Lujan and Armbruster 2011; Nutman, Windley, and Xiao 2007), which formed after intense periods of the subduction of the Mongolian and Guianan oceanic plates beneath the northern cratons of their respective continents (Chao et al. 1997; Voiçu, Bardoux, and Stevenson 2001).

On the Moon, those gradual cycles of heating and cooling occurred under a very different set of conditions, which are hypothesized to have formed the KREEP ${ }^{15}$ deposits (Shervais and McGee 1999). It is believed that the Moon formed after a Mars-sized object smashed into Earth and broke off debris that eventually consolidated into the Moon we recognize today. The power of the collision liquefied much of the debris tossed into space, which formed lunar magma. The lower density of the Moon left an ocean of this magma trapped between the mantle and the crust, which cooled very gradually, thereby enabling high concentrations of rare earths to coalesce (Heiken, Vaniman, and French 1991). Although the characterization of rare earth deposits in new sites along the global rare earth frontier tends to be prone to hyperbole, there is, nevertheless, a geological basis for the emergence of these three particular sites. 
Second, deposits alone are not reason enough for some places to be mined and others not. The existence of rare earth deposits does not, in itself, explain why a particular place emerges on the global rare earth frontier. In each of the sites, deposits were valorized into coherent bodies of geological knowledge. That knowledge circulated in a way that enabled political and economic actors to envision mining operations in these particular places as a means to achieve broader territorial objectives. Professional prospecting in remote regions is a high-cost and high-risk endeavor, often requiring the backing of the state, military, or major research institutions to catalogue the attributes of vertical territory. In all cases examined in this book, the discovery of rare earths generated little immediate interest within the larger territorial project of which geological surveying was one crucial component.

The timeline of exploration tells a story of successive territorial and scientific ambitions to conquer new frontiers. Baotou, São Gabriel da Cachoeira, and the Moon were sites of early twentieth century international geological prospecting as multiple states and empires sought knowledge, wealth, and territorial control. Dutch, Swiss, Japanese, and Soviet geologists visited Baotou, but the Chinese geologist Ding Daoheng is credited with discovering the iron reserves at Bayan Obo in 1927 and publishing his results in 1933. In 1935, a team of chemists discovered that the iron was associated with rare earths, which at that point played a marginal role in technological applications. Due to the Japanese invasion and the civil war, Bayan Obo remained undeveloped until the 1950s, although the Japanese imperial forces conducted some exploratory work in this area (Ding 1933; Ma 1995). In 1972, the Brazilian Geological Service identified sizable niobium-coltan-REE deposits at Morro dos Seis Lagos in São Gabriel da Cachoeira, which some analysts claim are the largest in the world (Gomes, Ruberti, and Morbidelli 1990; Orris and Grauch 2013). This deposit was further explored and mapped in 1975 by the Brazilian Federal Mineral Resources Research Company (Companhia de Pesquisa de Recursos Minerais) (Cuadros Justo and de Souza 1986). Other deposits in the region identified by indigenous and small-scale miners are located in alluvial deposits close to the surface, requiring minimal blasting which some claim would make production relatively cheaper provided infrastructural constraints could be overcome (Jacobi 2009). On the Moon, rare earth elements were identified in samples from the western lunar highlands brought back from the Apollo 12 and 14 missions and the Soviet Luna 16, 20, and 24 missions (Shervais and McGee 1999; Zak 2013). Lunar samples are legally available for scientific research to all countries (United Nations 1967). These rocks have been examined by international geologists visiting NASA and affiliated planetary science institutes, the Russian Space Agency, the European Space Agency, and the China National Space Administration. 
Initial international geological prospecting proceeded in these sites under broad mandates of scientific knowledge acquisition in the "peripheries" for global centers of power (Braun 2000). The precise geographical locations of "centers" and "peripheries" change over time. In the early twentieth century, these centers of power and calculation relative to Inner Mongolia were located in colonial European, imperial Japanese and Soviet states, and only toward the mid-twentieth century in Beijing. In the mid-twentieth century, the centers of calculation and power relative to the Moon were located in the space agencies of the Soviet Union and the United States. But this has shifted to include start-ups in the San Francisco Bay Area, and the dozens of space agencies and hundreds of contractors across the globe pursuing lunar mining. In the latter quarter of the twentieth century, the centers of power and calculation relative to the northwestern Amazon were located in Brasília, Manaus, and Washington DC, and since the turn of the millennium, China. Put another way, the expansion of rare earth technology and awareness of their potential economic and geopolitical importance revived dormant bodies of geological knowledge in global metropoles. This has reanimated the frontier imaginary among planners, financiers, inventors, and politicians who imagine personal and national prosperity built on exploiting rare earths in these "peripheries."

This is how frontiers are produced by extralocal powers reaching across immense distances to configure the space in question into something else (Tsing 2005). It is in the metropoles that political, economic, scientific, and military actors jockey, in oft-unexamined abstractions, to transform the unknown into the known. The raison d'être, in all cases, is the pursuit, production, and differentially controlled circulation of geological knowledge. Geological knowledge that is strategically valued imbues the territory in question with sense of verticality. This vertical sense of territory assigns different values to different layers of substrata. Under these conditions, it is possible to value subterranean resources in such a manner that devalues the lives and norms that define the surface. Each chapter illustrates how the history of rare earths mining is also a history of contestation over the value of landscapes and lives relative to the elements underfoot.

Which geological knowledge is recognized as legitimate and who is empowered to wield it is contested. In China, much geological data is treated as a state secret, a practice informed by a living memory of foreign occupation. With respect to the Moon, selenological knowledge has constituted part of the patrimony of all humankind since 1967. Any data gathered from lunar missions must be made available to any researcher regardless of nationality. In Brazil, there is a dynamic and at times violent interplay between local indigenous knowledge and federally recognized geological data used to grant mining concessions. In China and Brazil, state geological knowledge coexists and draws from local vernacular 
knowledge held by artisanal and black market miners. Far from objective, apolitical catalogues of vertical territory, the collection and circulation of geological data is crucial to multiple competing territorial orders. This is especially so when geological knowledge is mobilized to justify the enclosure and sacrifice of other peoples' lands.

Third, all three sites are characterized by partial, overlapping, or contested legal regimes. In Inner Mongolia, mining activities intersect with economic development, minority protection, and conservation laws. The first concerns the strategy to "Open Up the West" and to better utilize the autonomous region's mineral resources in service of the national mandate of "All-Around Scientific Development" (He 2009). The second requires that local pastoralists' livelihood interests be protected, meaning that mining cannot proceed without consent from and compensation for impacted pastoralists. Enforcement lies with both the local bureau of land and resources, and the head of the village collective, which often have conflicting interests. The third concerns a set of environmental protection laws containing quotas on the proportion of grassland that can be used for purposes other than conservation or grazing. Coordination or harmonization of these laws in practice has been partial at best; local, autonomous region and national leaders concede that economic resource needs (i.e., mining) ${ }^{16}$ supersede other concerns. The contradiction is material and immediate. Inner Mongolia's mineral wealth lies beneath the grassland resources fundamental to pastoralist livelihoods. These overlapping laws result in periodic violence between local leaders, mining bosses and their employees, and local pastoralists (Agence-France Presse 2015; Jacobs 2011; Reuters 2011). But because rare earth elements are classified as strategic national resources, the Bayan Obo mining district has been re-zoned to legally erase possible conflicts: officially, there are no farmers or pastoralists in Bayan Obo. This is of course not true-during fieldwork in 2013 I noted at least thirty agropastoral homesteads in the vicinity of the mine. But there is no longer a local census category for farmers. Land is zoned according to three uses: mining, urbanization, or wind energy generation. Livelihoods that do not fit within these zoning codes-whether agropastoralism or artisanal mining-are not counted and therefore exist in precarious relation to the local state.

In Brazil, ecological and indigenous legal protections overlap with Amazonian border security laws, which designate all land within sixty kilometers of the national border to be part of the Calha Norte (northern trench) under the exclusive domain of Brazil's military. The deposits at Morro dos Seis Lagos lie sixty kilometers south from the borders of Colombia and Venezuela within two national parks. One, Neblina Peak National Park, was established by executive decree in 1979, by the military-appointed President João Figuereido following failed migration and construction campaigns. The second, Morro de Seis Lagos State Biological Reserve, 
was established by the state of Amazonas in 1990 as part a land management and zoning plan, which ostensibly provided employment and land use entitlements for indigenous inhabitants. In 1992, twenty-three indigenous groups were granted qualified sovereignty in their respective indigenous Lands created by an executive decree of President Fernando Collor de Mello. No one, not even the military, is permitted to enter indigenous lands without permission. Yet no one but the military is permitted in the Calha Norte, which overlaps with indigenous lands where periodic small-scale mining takes place. Therefore in remote Amazonian border regions, two groups are legally granted exclusive access and are also legally excluded from the lands in question. In light of the 2011 presidential invitation to open up Brazil's Amazonian reserves as well as grassroots efforts to decriminalize small-scale mining of rare earths, coltan, and gold, long-standing campaigns to rescind the moratorium on mining in indigenous lands were revived by state, corporate, and indigenous actors (Jucá 1996). This means that in the absence of a single definitive and enforceable contemporary legal convention, multiple actors engage in semi-legal prospecting, extraction, and export.

The Moon is governed by two international legal conventions, against which, to date, the United States and Luxembourg have passed legislation to support private property claims. The 1984 Agreement Governing the Activities of States on the Moon and Other Celestial Bodies, also known as the Moon Treaty, bans any ownership of extraterrestrial property by any entity. It requires that an international regime and protocols be established "to govern the exploitation of natural resources of the Moon as such exploitation is about to become feasible" (United Nations 1984, Art. 11, Para. 5). Preceding this is the 1967 United Nations Treaty on Principles Governing the Activities of States in the Exploration and Use of Outer Space, including the Moon and Other Celestial Bodies (OST). The OST frames outer space as the patrimony of all humankind and prohibits assertions of national sovereignty. However, designating the Moon as the patrimony of all humankind effectively reconfigures it as a global commons, which makes it vulnerable to processes of appropriation and enclosure that have characterized the fates of commons elsewhere (Beery 2011). There are two primary interpretations regarding the applicability of the prohibitions against national appropriation to private enterprise. The first argues that limits on national sovereignty do not apply to private enterprise. The second argues that private appropriation must be backed by the state in any case, so private appropriation is state appropriation after all, and therefore prohibited (Carswell 2002). Private sector actors have mounted a regulatory offensive, propagating the fiction that no legal conventions govern the Moon. It is instead a "wild west" (Klotz 2015) that demands US government intervention to protect the rights of US citizens to own and exploit lunar territory against the threat of a "Chinese colony" (Bigelow quoted in Moskowitz 2011). In November 2015, 
US president Barack Obama signed the Spurring Private Aerospace Competitiveness and Entrepreneurship Act of 2015, which recognizes the private property rights of US citizens to outer space resources.

In the three cases examined herein, as well as several others beyond the scope of this book, rare earth mining has required a regulatory offensive on the part of promining interests in order to transform laws otherwise established to protect local societies and environments. This is what a frontier narrative does: it conjures a space of regulatory chaos in order to reconfigure laws in a manner that is hospitable to extralocal mining interests. Each of the sites illustrates a different form of this process. In Bayan Obo, an entire census category and zoning code was eliminated in order to erase competing local claims. In Brazil, the question is not whether mining should proceed at all. Rather, the question is which sort of mining regime-extralocal or indigenous-will succeed in having legal changes made according to its terms. With respect to the Moon, the regulatory offensive aims to create the conditions of possibility for private, state-backed enclosure. This would effectively undo robust treaty regimes inhospitable to private sector accumulation.

In all cases, the regulatory offensive is preceded by a discursive offensive, which brings us to the fourth point of comparison. Baotou, São Gabriel da Cachoeira, and the Moon have been discursively cast as "sacrifice zones" whose destructionwhile perhaps contested or publicly lamented—has been promoted as necessary for shoring up context-specific notions of military, territorial, or economic security in the name of a greater good. For example, in central government discourse, Bayan Obo is "the rare earth capital of the world," and "a model strategic resource development site" crucial to China's rise (Baogang Xitu 2013). This status is built on tremendous sacrifice. Arsenic, fluoride, thorium, and heavy metals contaminate surrounding soil and water, poisoning livestock and people living nearby and far downstream because of inadequate pollution control measures. For over four decades, this mode of rare earth production suited China's broader development goals and critically co-constituted the global division of toxic labor under neoliberalism - until the twenty-first century. As detailed in chapter 3, China's central government then began to take steps to control production in the face of growing local research and activism that illuminated an epochal threat to one of the key water sources for north and northeastern China. Prior to late 2010, production practices in Baotou and Bayan Obo scarcely caught international attention, with the exception of some investigative journalists (Hilsum 2009) and antirenewable energy lobbyists seeking to expose "clean energy's dirty little secret" (Margonelli 2009). Following the crisis, Anglophone discourse "racially coded" (Chen 2011) toxic mining practices as both a "Chinese" problem as well as a "dirty trick" played by China's central government in order to achieve dominance in rare earth production. 
In São Gabriel da Cachoeira, actors within the federal government have been working with corporate mining interests to renege the moratoriums on mining in indigenous lands in order to "develop the world's largest strategic minerals deposit" and "improve Brazil's position in strategic resource markets." ${ }^{17}$ Because of the known hazards of rare earth mining, as well as the extensive history of sovereign anxieties with respect to the region, planners in the military and federal government see large-scale mineral exploitation as a way to kill two birds with one stone. After all, infrastructure construction, industrialization, and resource extraction proved effective to industrialize and rationalize China's northwestern frontier. As the reasoning goes in corridors of power, many lives were lost, great sacrifices were made, but China modernized into a superpower, so Brazil should follow the same process. Planners and policymakers in Brazil have hoped to formulate a version of China's northwestern development strategies in order to integrate and capitalize on the resources of the Amazon. ${ }^{18}$

Private space mining entrepreneurs and their legal advocates idealize the Moon as a consequence-free terrain for resource exploitation ostensibly "for the benefit of all humanity," (Moon Express 2013). In their view, space mining must happen in order to rescue the human race, which is otherwise condemned to unavoidable destruction of Earthly resources. In policy, industry, and academic literature, the push to develop extraglobal extraction technology is legitimated according to the apocalyptic imaginary of Earth as planetary sacrifice zone, where neoMalthusian nightmares prevail as we succumb to scarcity-induced civilizational collapse (Autry 2011; Dolman 2002; Dudley-Flores and Gangale 2013; Guner 2004). Among these actors, the greatest appeal of the Moon is the likelihood of near total automation of mining activities, and the lack of requirements for environmental and social impact assessments. The appeal of a putatively consequencefree terrain for extractivist adventure is charged with neo-Cold War fears over which civilization will be rescued by off-Earth mining: that of China, Russia, or the West? ${ }^{19}$ In this view, whichever firm or country first transforms the off-Earth frontier into an extraterrestrial hinterland is a matter of central geopolitical importance. The questions of whether and on what terms outer space should be mined are subsumed by hawkish preoccupations with who will win the race to enclose lunar space and beyond. As detailed in chapter 6, these ideations have spawned a multipronged effort to devalue the Moon, to cast it as ungoverned and inessential to life on Earth.

In all cases, nationalist and geopolitical discourses surrounding rare earth elements argue that destructive mining must be permitted because rare earths are essential to the infrastructure and hardware of global modernity. As shown in subsequent chapters, who is subject to the devastation and who is spared is arbitrated in part by raced and gendered notions of difference in which some 
landscapes and lives are designated as more sacrificable than others. This definition of the greater good sets up a false notion that terrible health and environmental devastation are the unavoidable price to pay for sourcing rare earths. Abundant research on recycling and flex mining shows otherwise (Binnemans et al. 2013; Knapp 2016; Verrax 2015), suggesting that it is not for lack of more just and sustainable alternatives that rare earth sourcing comes at such a high social and environmental cost. Rather, imposing sacrifice through the hazards of mining in specific places serves economic and geopolitical ends. Narrow economic ends are served by dodging the required investments to clean up the lifecycles of rare earths and rare earth-bearing products. Disciplining or capturing historically elusive territory serves geopolitical ends. These ends constitute much of the so-called greater good served by rare earth prospecting and extraction. The real (in the sense of material goods produced) and the imagined (in the sense of points scored in global geopolitical and economic contests) are inextricably intertwined in the production of the rare earth frontier.

Finally, in all three sites rare earth exploitation, in itself, is an absurd proposition that defies straightforward market logic. Rather, it is from the geopolitical perspective-both conventional and critical - that the importance of these particular sites to the global rare earth frontier begins to make any sort of sense. Geopolitics is the optic through which states organize territorial politics. The strategic significance of these particular commodities gives "exploration and development ... a praetorian cast," producing "a frontier of violent accumulation working hand in hand with militarism and empire" (Watts 2012, 438). Local resistance to the privations preceding and resulting from large-scale rare earth mining generates, in military and firm parlance, security problems. At the project sites, security problems are dealt with by the "securitization" of space at further expense of local autonomy. In other words, resistance to sacrifice tends to be met with the imposition of still greater regimes sacrifice in order to maintain or advance a territorial order defined by extractive geopolitics.

The myths of the rarity of the elements with which these sites are endowed amplify their already privileged position in nationalist dreams of territory. These rare earth frontiers are imbued with mythic significance in dominant national imaginaries insofar as they are framed as exotic, undeveloped, or inalienable parts of the national patrimony nevertheless at risk of expropriation by foreign actors. These dynamics which so powerfully define Baotou and São Gabriel da Cachoeira in their respective national polities also illuminate the sorts of spaces that have been sought for reconfiguration into a resource hinterland: specifically marginal, contested spaces. While the putative marginalities of these places both precedes and lends itself to the reconfiguration of these spaces into sites of extraction on the 
global rare earth frontier, such marginality is not given a priori. As subsequent chapters show, these frontiers and their marginalities were produced through hotly contested territorial exercises of imperial, colonial, and state power over time. No place is marginal unless it is forcefully produced as such; marginality implicates the gaze of extralocal power. Their imagined status as marginal does two kinds of work: it legitimates their framing as sacrificable while simultaneously recasting them as vulnerable points that need to be secured for the sake of national sovereignty or geopolitical power.

Indeed, "sacrifice—of people, places and things—is part and parcel to security geopolitics" (Brownlow and Perkins 2014). Security geopolitics are multivalent on the rare earth frontier. First, the space of exploitation itself is geopolitically significant: Baotou and São Gabriel da Cachoeira are in historically contested border regions; the Moon represents "the ultimate military high ground" (Dolman $2002,151)$ and the "most compelling" piece of off-Earth real estate that is "under threat" of Chinese colonization (Faust 2011). Second, security geopolitics are reflected in a number of trade, policy or production measures formulated in response to the threat of rare earth scarcity and the presumed military, technological, and economic vulnerability that would result. ${ }^{20}$ Third, when historically contested resource extraction is at issue, security geopolitics encompass not just the land in question, but the infrastructure, transport, and processing spaces as well as local labor and reproductive regimes. Each must be controlled against outside threats, real or imagined, whoever the outsider may be. In the case of the Moon, this is illustrated by the agitation of aspiring space miners to capture legal rights of exclusivity to their as-yet hypothetical mining claims. In the case of the Bayan Obo mining district within Baotou municipality, this is manifest in the decades-old prohibition against foreigners in the vicinity of the mine. In São Gabriel da Cachoeira, indigenous peoples remain outsiders on their own lands and within the nation of Brazil so long as outside firms receive mining licenses while indigenous peoples are prohibited from any economically motivated extraction on their own lands.

Because Baotou, São Gabriel da Cachoeira, and the Moon are geostrategically desirable frontiers, resource exploitation is also a means of territorialization. This is evident in the terms in which claims to the resources are framed. Marshaling capital, rewriting laws, and imposing regimes of enclosure-based social control to open up and develop these places are considered necessary in hegemonic political, economic, and technological progress narratives, which I examine in subsequent chapters. These visions, though broad and sometimes incoherent, are specific in their designations of who bears the mandate to execute the geopolitical agendaat whose expense-within the broader push to conquer the rare earth frontier. 


\section{The Research}

Rare earths are at the forefront of many global changes. The geography of their extraction both reflects and results in significant global shifts. Understanding these changes requires research that is grounded and global in scope (see figure 2). Rather than attempt to squeeze the local and global complexities of the questions at hand into a set of "impacts" and "outcomes," geography embraces the material and meaningful complexity characterizing a given issue, and examines the unfolding relationship between humans and the environment as a dialectic. This means not only focusing on the mutually influencing interactions among multiple competing actors and interests, but also interrogating the surrounding discourses, or what is taken to be common sense about the issues at hand.

To unpack the strange geography of the global rare earth frontier, I analyzed literatures, archives, expert interviews and ethnographic data across the Anglophone, Sinophone, and Lusophone world, which I gathered in China, Brazil, Germany, Australia, and the United States between 2010 and 2015. The multilingual approach is central to this project, not least because multiple forms of knowledge are evident in the discourses on rare earth elements within the English-speaking world. More still are present in the Portuguese and Chinese spheres. There is a symmetrical inaccessibility to the working rationales across language barriers even as these rationales interpenetrate to shape thought and action across global space. This symmetrical inaccessibility has been deeply reinforced by colonial and Cold War epistemological divisions of the world into mutually unintelligible "areas." The result is that knowledge about rare earths has tended to be formulated reactively during troubled times, and is therefore rife with generalizations amenable to the politically expedient discourses of the given context: among lobbyists and entrepreneurs in Washington, DC, for instance; in the state-run newspapers of Inner Mongolia, or among competing policymakers in Brasília.

Discourses have power. As systems of representation-even when the representations differ wildly from reality-they carry tremendous political power because they shape thought and action in consequential ways (Hall 1992). In Anglophone, Sinophone, and Lusophone discourses, I examined how multiple sets of knowledge from diverse actors and regions entangled with the ongoing production of the global rare earth frontier. As our contemporary global rare earth situation demonstrates, discourse and practice need not be precise or coherent to get results. In fact, fictions abound on the rare earth frontier. Black market and clandestine mining provide a sizable proportion of the oxides in circulation, and each new deposit is fabled to be the largest in the world. Critical natural resources, prospectors' dreams, and nationalist passions generate a politically potent mix of developmentalist mandates that need not ever be attainable in any basic, grounded sense in 
order to alter the fortunes of empires, to erase a human landscape, or to perpetuate a war, especially when there is money to be made and territory to be claimed. Furthermore, the complex contingencies of local and global factors - which includes environmental constraints, prospector's tales, citizen activism, investment vicissitudes, and changing prices and political sentiments crucial to the global rare earth economy - mean that development and industrialization agendas hardly proceed as planned. It is a mistake to assume that marshaling the capital, technology, labor, and political will to capitalize on the 2010 crisis and actually opening a new site on the rare earth frontier are the same thing, as it is likewise a mistake to assume mandated production improvements, particularly those concerned with technological fixes to environmental and labor hazards (Shaiken 1986) actually manifest in practice. ${ }^{21}$ As this research shows, which deposits are identified as promising and where rare earths are mined has less to do with an allegedly exceptional geological incidence than with a host of other agendas and negotiations, which are simultaneously distinct to their own contexts and related across the multiple sites examined herein. Examining how these distinct histories intersect to form our contemporary rare earth situation brings us closer to a truly global understanding of the issues.

By taking such an approach, I contend that the processes shaping Baotou, São Gabriel da Cachoeira, and the Moon: first, had something to do with each other; second, could be understood in critical comparative perspective; and third, that such a perspective raises important new questions about global arrangements of power and production while clarifying the epistemological foundations of the old arrangements received from the twentieth century. Each of the three sites have been selected to provide a window into the past, present, and prospective instances where rare earth prospecting, mining, and processing served as commodity-based means to the territorial and geopolitical ends of conjuring and taming frontier spaces. To examine the histories and the relations among these sites within the framework of global political economy, I adopted an encompassing comparative approach that considers each site in their transnational historical contexts. Rather than search for equivalent parts in each site or choose one site to uphold as the "norm" against which to measure all other sites, ${ }^{22} \mathrm{I}$ identified analogous yet distinct processes of territoriality, subject formation, and nation building unfolding in the dialectical production of several key frontier spaces.

My methodological toolkit for researching these processes included analyzing multiple actor-networks, conducting semi-structured serial interviews with a diversity of actors at multiple scales over several years, and completing archival research in China, the United States, Brazil, and Germany. The purpose of my multiscalar inquiries was to understand whether and how rare earth elements intersected with site-specific economic, cultural, political, development, and security issues, as understood by actors in multiple institutions and individuals with 
multiple stakes in these issues. This meant selecting interviewees who were engaged in rare earth prospecting, production, or trade, as well as selecting those who worked specifically on broader development or security issues in or in relation to the primary sites. In practice, it meant conducting hundreds of meetings in local languages over the years. The purpose of the archival research was to identify historical records of exploration of the sites. In these records, I traced the genealogy of the frontier narrative and placed the role of geological exploration within such histories in order to identify the circumstances under which rare earth elements became strategically valued.

This research was built around immersion in the sites where such frontier spaces are produced. While this includes the primary sites (with the exception of the Moon, of course) it also includes the loci of extralocal power relative to each of the sites. These were located in offices in state and national capitals, in the private cars of powerful officials, in the penthouse bars frequented by billionaire investors, in the heady gatherings of aspiring space miners, in the frontier outposts of police and military, in the modest homes of the laborers literally building these places into being, and in the settlements and shanties of displaced people and clandestine miners. I was able to move across such spaces because of my fluency in multiple languages, facilitated by existing networks built over a decade of life and work in Brazil, China, and the San Francisco Bay Area. But experience and networks are not enough. To execute a project of this scope, the moral and material backing of globally renowned academic institutions and the financial support of the National Science Foundation were crucial.

The sole mandates of my academic and funding institutions were to adhere to ethical codes of conduct and to share my findings with diverse audiences in an ongoing manner to broaden the positive potential impacts of this work. My questions and my data were beholden to no one. These ethical mandates and this freedom of inquiry validated my role as an academic researcher working in the interest of a global public and opened more doors than I could have imagined. So too did the novelty of my multisited approach: in each place-Brazil, China, the United States-my experience in the other two places tended to spark interest among interviewees and in general favorably disposed people from all walks of life to talking with me.

When embarking on extensive ethnographic and archival research, there are a number of sources one can rely on for preparation. Mentors provide invaluable guidance, but so too do one's peers, the growing body of useful publications, and of course, the lessons of one's own experience. But there was one aspect of fieldwork for which I had no way of preparing: the suspicion, encountered at home and abroad, that I was a spy. 
In Brazil and China, police and military personnel routinely joked that I was a CIA agent. Such jokes carried an edge: in both countries, terrible atrocities have been visited on innocent people as part of US intelligence operations. This is a history I denounce but whose legacies I cannot escape: periodic revelations highlight the fact that there are plenty of US citizens abroad who simply are not who they claim to be. Such jokes immediately threw differences of power and privilege between myself and my local interlocutors into sharp relief. The mere suggestion that I might be a sensory organ of the US government extending into the intimate spaces of homes and offices on other continents sometimes complicated efforts to build trust, and other times poisoned local rituals of hospitality with fear.

At home in the United States, friends and family unfamiliar with the practice of international ethnographic work would joke that more likely than being a geographer I was probably a spy. Why else would anyone go to remote places, learn the languages, and endure the physical and emotional hardships of life on the frontier? Who but a spook would cultivate the social skills to move from the highest corridors of power to the humblest frontier dwelling? This variety of common sense seemed to maintain that one would embark on grounded ethnographic research on a topic imbued with international strategic significance only if ordered to do so. The extent of this rather paranoid view was driven home at the conclusion of my research, when I received a visit from US intelligence agencies that, as far as I could discern, were attempting to assess whether I had been recruited to spy for China. Such a visit belies the hostile edge between the two most interdependent economies in the world, but also had a chilling effect on my follow-up research plans. How to proceed when social science research is under watch as a potential crime against the state? For someone whose formative years were defined by the triumphalist discourses of US democratic freedom over Soviet totalitarianism, to be suspected simply for pursuing academic research provided me a glimpse of how deeply totalitarian tendencies had metastasized in my home government.

When such suspicions were not offensive they were deeply troubling. They suggest a dismal worldview, one in which international researchers are not ambassadors for peace but potential traitors, where intellectual labor is performed only by tools of a totalizing state apparatus, where shedding light on contemporary global problems is a classified act rather than a civic duty. Such a worldview seems to forget that governments and firms are made of people to whom we are, at a minimum, entitled to pose questions. If we wish to make sense of seemingly intractable global problems, we must not confine ourselves to the classes, cultures, and places in which we feel at home and unchallenged. To wish to demystify an issue that is profoundly changing the way people relate to the environment and each other across the global space, with the humble hope of informing better practices 
to reduce needless suffering, is reason enough to do research. One need not be a tool to travel afield in search of answers.

To investigate an issue around which so much speculation, hyperbole, and fictions swirled, I conducted repeat visits over several years, triangulated multiple forms of data, and examined how stories cohered, contradicted, and changed over time. This sometimes involved huddling in unheated homes in the sub-zero temperatures of an Inner Mongolian winter, and sometimes involved improvising ways to smooth the wrinkles out of my clothes and the scuffs from my shoes for meetings in the great halls of national ministries. Other times, more than I would care to remember, it involved going through the elaborate drinking rituals essential to building trust in corridors of power and frontier outposts alike. In the same week, I might share meals with mining millionaires, and then bathe in the tap water so polluted by their industries that sores erupted on my skin.

Such variability defined most of the fieldwork process. Accessing archives was no exception. On some occasions, civil servants greeted my requests for information by literally opening their files for me to peruse, grateful for another set of eyes on a seemingly intractable problem. Other times, gathering fragments of historical data required sitting in the empty waiting area of provincial archives for days on end for no other apparent reason than that the archivist was in a foul mood.

I often visited the same place through different means. The first time I might pass through an area in the private jeep of a local power broker, and the second time on a motorcycle guided well away from paved roads to visit clandestine mining sites. Covering a lot of ground also meant being present for whatever unfolded while I was in a particular place. I abided the fear and rage that tore through a community following a land dispute that ended in murder. I stood with a grieving family at the bedside of a cancer victim poisoned by decades of accumulated toxins in the waters and soils of their village. Bearing witness to these unanticipated tragedies illuminated the stakes of the research in ways no amount of discussion could.

Many of these stories, compelling as they are, would reveal too much about specific people in places where talking to outsiders could have negative consequences. Although it was my privilege to hear these stories and to participate briefly in multiple lives, it is not my prerogative to recount their details here. To honor the integrity of those who risked talking with me without burying the significance of what they shared, I use these intimate and sometimes inflammatory accounts as maps to navigate the complex terrains surrounding the rare earths on which we all depend. I used what was shared with me in confidence as a way to decode and curate information that is publicly available and therefore verifiable. Where I cannot relate certain testimonies from the rare earth frontier, I instead illuminate the forces that create such stories to show how they comprise our present moment. 